\title{
Pengukuran Kualitas Kecepatan Angin Pada TEROWONGAN ANGIN DI ILST BBTA3
}

\section{MEASUREMENT OF Wind SPEED QUALITY FOR WIND TUNNEL AT BBTA3}

\author{
Novan Risnawan' ${ }^{1}$, F. Andree Yohanes ${ }^{1}$, Sunarno ${ }^{1}$, Hetty Novianti' ${ }^{1}$, Yusron Feriadi ${ }^{1}$ \\ ${ }^{1}$ Balai Besar Teknologi Aerodinamika, Aeroelastika dan Aeroakustika - BPPT \\ Kawasan PUSPIPTEK Gedung 240, Setu, Tangerang Selatan - Banten, Indonesia
}

\begin{abstract}
Abstrak
Pengecekan hasil kalibrasi besaran-besaran acuan aliran terowongan angin ILST telah selesai dilakukan pada awal tahun 2018. Pengecekan kalibrasi dilakukan terhadap koefisien kalibrasi tekanan statik dan tekanan dinamik terprediksi. Koefisien-koefisien referensi terowongan angin ini disesuaikan dengan tekanan statik dan tekanan dinamik yang dibaca oleh pitot tube acuan yang dipasang di tengah turn table di dalam seksi uji. Pengukuran dilakukan pada kondisi seksi uji kosong (empty test section). Hasil pengecekan kalibrasi acuan ini sangat dekat dengan hasil sebelumnya. Hasil kegiatan ini secara umum menunjukkan bahwa kualitas aliran terowongan angin ILST masih terpelihara dengan baik untuk keperluan pengujian aerodinamik.
\end{abstract}

Kata Kunci : Kalibrasi terowongan angin, referensi terowongan angin.

\begin{abstract}
Calibration check of Indonesia Low Speed Wind Tunnel (ILST) flow reference value have been performed at the beginning of 2018. Calibration check have been conducted to the calibration coefficient of predicted freestream static and dynamic pressure. This wind tunnel reference values is reffered to the static and dynamic pressure of a reference pitot tube that is installed at the center of turn table inside the test section. The test is conducted in empty test section. The calibration check result is very close to the previous values. This result show that flow quality of ILST wind tunnel is still maintained well for aerodynamic testing purposes.
\end{abstract}

Keywords: Wind tunnel calibration, tunnel reference value.

\section{Pendahuluan}

Terowongan angin digunakan dalam penelitian aerodinamika untuk mempelajari karakteristik aliran udara. Terowongan angin digunakan untuk mensimulasikan keadaan sebenarnya pada suatu benda yang berada dalam pengaruh gaya-gaya aerodinamika dalam bidang aeronautika, serta menganalisis kinerja mekanika terbang (flight mechanic) dari suatu benda terbang (aerial vehicle). Selain itu, terowongan angin juga banyak digunakan dalam pengujian berbagai kondisi benda dalam aliran udara.

Terowongan angin ILST merupakan terowongan angin dengan kecepatan rendah (Low Speed Wind Tunnel) yang pada beberapa tahun perancangan dan pembangunan merupakan salah satu terowongan angin yang terbaik di dunia dengan kualitas aliran yang baik, sehingga guna memastikan bahwa kualitas aliran angin di terowongan angin ILST konsisten, dilakukannya uji kalibrasi terhadap kualitas aliran di terowongan angin tersebut diantaranya dengan melakukan tes uji kualitas aliran pada seksi uji kosong dengan menempatkan pitot setatik probe di titik tengah seksi uji tempat di mana model uji diletakan.

Kecepatan angin di terowongan angin biasanya diukur dengan menggunakan pitot setatic tube yang di letakan di tengan seksi uji, namun ketika ada model yang terpasang di seksi uji tersebut maka kita tidak

* Novan Risnawan. Tel: +62 217560902

E-mail: novan.risnawan@bppt.go.id dapat menemukan pitot setatic tube yang terpasang di tengah seksi uji yang berfungsi untuk mengukur 
kecepatan angin yang mengalir di sekitar area seksi uji dari inlet hingga outlet aliran pada seksi uji. Untuk mengetahui kecepatan angin yang mengalir di area seksi uji maka di perlukannya referensi yang akan di gunakan untuk menentukan kecepatan aliran angin. Kalibrasi terowongan angin yang di lakukan pada seksi uji kosong yang di lakukan bertujuan untuk menemukan kolerasi matematis untuk mengontrol tekanan (Tunnel Control Pressure) pada terowongan angin, dan tekanan di pusatkan pada turn table (meja putar) di tengan titik pusat seksi uji dimana model uji yang biasanya di letakan, sebagai tambahan bahwa kecepatan angin di sekitar seksi uji terowongan angina dapat di tentukan korelasinya dengan secara matemais terhadap tekanan di sekitar meja putar (Turn Table) dan fariasi RPM motor atau turbine, namun hal ini juga harus di koreksi dengan lingkungan di sekitar terhadap pengaruh perubahan variasi suhu dan kelembaban di area seksi uji.

\section{KAJIAN TEORI}

\subsection{ILST}

Terowongan angin ILST (Indonesian LowSpeed Tunnel). ILST merupakan "terowongan angin sirkuit tertutup" yang memiliki seksi uji dengan penampang $3 \mathrm{~m} \times 4 \mathrm{~m}$, dengan panjang $10 \mathrm{~m}$, bertekanan atmosfir (atmosphere pressurized) dan kecepatan angin maksimum $80 \mathrm{~m} / \mathrm{s}$ dengan Mach Number 0.2. Seksi uji dari terowongan angin ini dilengkapi dengan dua buah turn table atas dan bawah dengan diameter $3 \mathrm{~m}$ yang bergerak secara sinkron. Turn table ini dapat diputar hingga \pm 90 derajat. Terowongan angin dilengkapi dengan honeycomb dan tiga lapis fine turbulence screen. Variasi kecepatan angin di dalam seksi uji kurang dari $0.2 \%$ dari harga rata-rata. Variasi tekanan static dalam arah aliran dalam rentang $\pm 0.3 \%$ dari tekanan dinamik pada kecepatan $70 \mathrm{~m} / \mathrm{s}$. Flow angularity \pm 0.1 derajat untuk pitch dan \pm 0.2 derajat untuk sudut yaw.

Penampang akhir seksi uji sedikit lebih besar, inklinasi terhadap sumbu penampang sekitar 2 derajat untuk menjaga deviasi bouyancy di dalam seksi uji sekecil mungkin. Lapisan batas di sekitar dinding seksi uji memiliki ketebalan sekitar $11 \mathrm{~cm}$ pada sisi kiri dan kanan, dan $13 \mathrm{~cm}$ pada bagian lantai dan langit-langit. Dengan demikian blockage area dari seksi uji adalah 90\% dari luas penampang seksi uji.

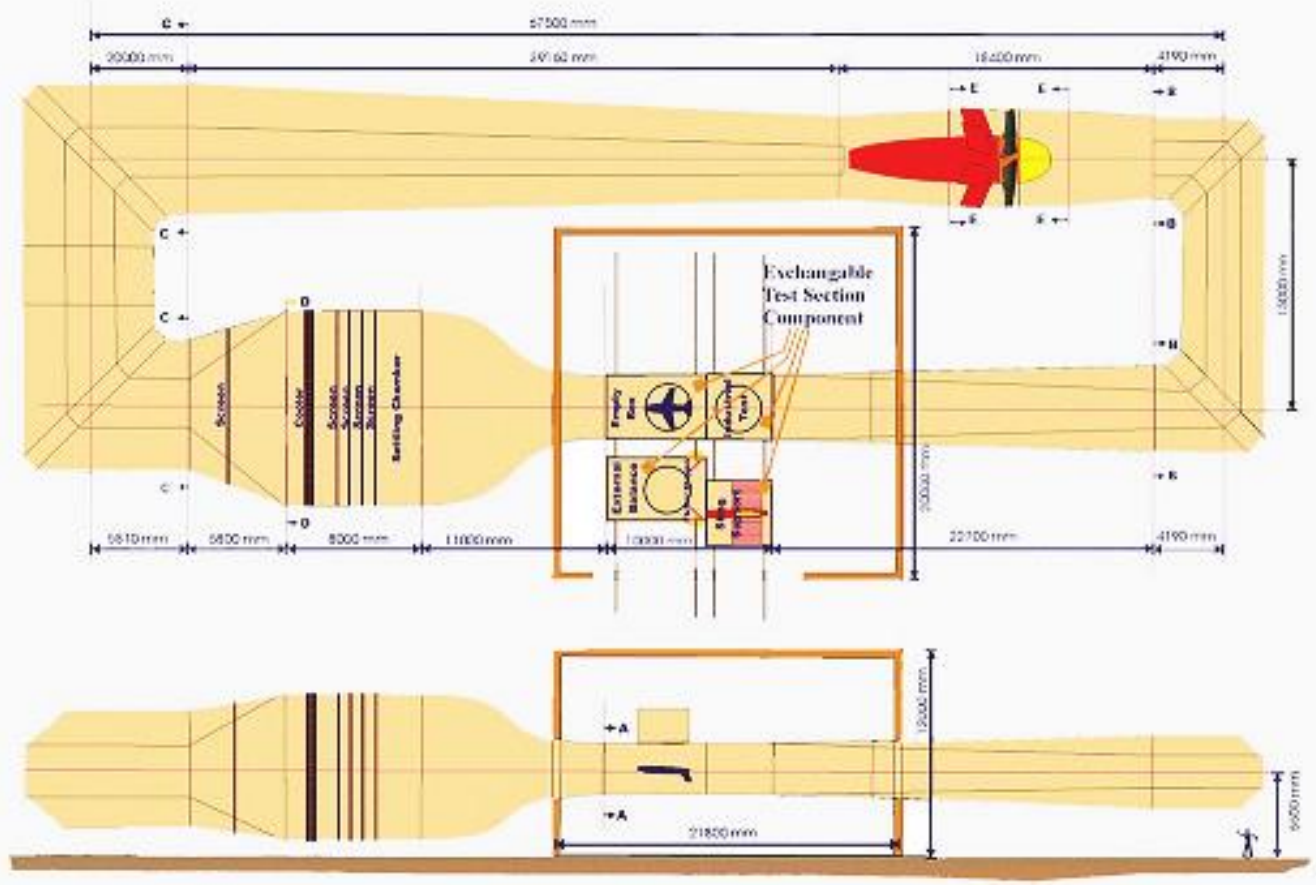

Gambar 1. terowongan angin jenis tertutup ILST-BBTA3

\subsection{Instrumentasi}

Instrumentasi digunakan untuk untuk mengetahui dan mendapatkan data aliran angin, sehingga di perlukannya penempatan seketsa lokasi pada tekanan total dan temperature yang harus di ketahui di bagian dalam kontraksi seksi uji serta agar bisa mengkoreksi nilai yang di dapat dari tekanan setatik dan 
tekanan dinamik. Sebagai setandar terowongan angin di seluruh dunia, parameter referensi adalah temperature, tekanan setatik, dan tekanan dinamik di dalam bagian kontraksi seksi uji, oleh karena itu pada bagian kontraksi seksi uji harus di lengkapi oleh beberapa instrumentasi yang mendukung seperti halnya probe tekanan total $\left(\mathrm{P}_{\mathrm{t}}\right)$, probe temperature $\left(\mathrm{T}_{\mathrm{c}}\right)$, dan tekanan setatik $\left(\mathrm{P}_{\mathrm{s}}\right)$, dapat di lihat pada gambar sebagai berikut:

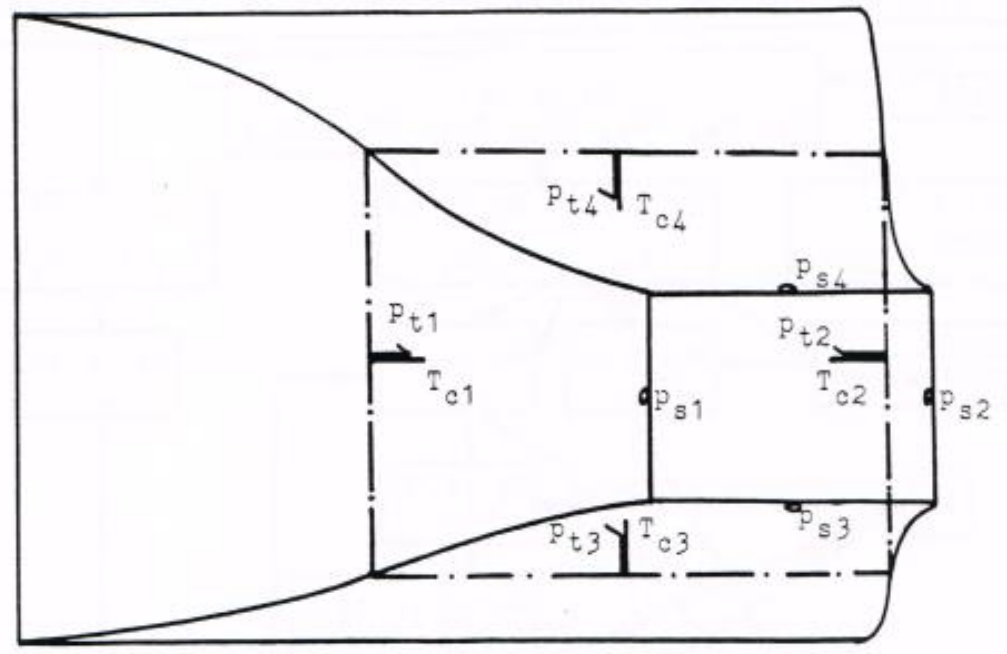

Gambar 2. Lokasi Temperatur $\left(T_{c}\right)$, Total Pressure $\left(P_{t}\right)$ probe di dalam kontraksi seksi uji dan lokasi lubang tekanan setatik $\left(\boldsymbol{P}_{s}\right)$ pada bagian akhir kontraksi seksi uji. (O.De Vries Gambar 2. Hal.135).

Gambar di atas menunjukan bahwa :

1) Empat tekanan setatik di pasang di empat dinding pada ujung belakang kontraksi seksi uji.

2) Empat tekanan total probe di pasang pada empat dinding di empat dinding kontraksi seksi uji.

3) Dua temperature probe pasang di lantai dan langit-langit pada kontraksi seksi uji.

4) selin itu juga untuk memantau kinerja dari fan drive dengan dua tekanan setatik yang di tempatkan di fan yang saling bersebrangan (across the fan), yang berada di area downstream dan upstream.

Untuk mengontrol tekanan di dalam terowongan angin baik yang absolut maupun yang diferensial masing-masing akan di ukur dengan menggunakan HIL (High Level Interface), dengan beralih (by switch) makan bisa untuk memilih seberapa besar tekanan kontrol yang akan diukur, beralih (switch) pada kondisi setandar bisa di gunakan untuk menghitung data pada aliran di terowongan angin, untuk memiliki pembacaan tekanan yang setabil dan akurat, tekanan dalam referensi terowongan angin ILST diperoleh dari konfigurasi tekanan tranduser seperti yang tercantum dalam tabel sebagai berikut:

Tabel 1. Tunnel tranducer untuk referens tunnel

\begin{tabular}{|c|c|c|c|}
\hline \multirow{2}{*}{ Switch On/Off } & \multirow{2}{*}{ Measured } & \multicolumn{2}{|c|}{ Tranducer } \\
\cline { 2 - 4 } & $P_{s}$ & $80-110 \mathrm{kPa}$ & Absolute/differential \\
\hline \multirow{4}{*}{ On/Off } & $P_{t 3}$ & $80-110 \mathrm{kPa}$ & Absolute \\
& $\Delta P_{s} 14=P_{s} 1-P_{s 4}$ & $620 \mathrm{kPa}$ & Absolute \\
& $\Delta P 24=P_{s} 2-P_{s 4}$ & $620 \mathrm{kPa}$ & Differential \\
& $\Delta P 34=P_{s 3}-P_{s 4}$ & $620 \mathrm{kPa}$ & Differential \\
& \multicolumn{2}{c}{} &
\end{tabular}

\subsection{Pengontrol Tekanan di Terowongan Angin}

Tunnel control pressure terdiri dari tekanan setatik dan tekanan diferensial, untuk mengontrol tekanan di terowongan angin diperlukan nilai dari rata-rata tekanan setatik $(\mathrm{Pc})$ dan nilai rata-rata dari tekanan diferensial $(\triangle \mathrm{Pc})$ (Total dikurangi setatik). Definisi dari keduanya dapat di jelaskan dibawah ini, adalah sebagai berikut:

\# Kontrol tekanan setatik, tekanan ini di definiskan sebagai berikut:

Pengontrol tekanan setatik adalah rata-rata nilai tekanan setatik yang di gunakan untuk mengotrol terowongan,

$P_{c}=\left(P_{s} 1+P_{s} 2+P_{s} 3+P_{s} 4\right) / 4$ 
(O.De Vries. Hal.34)

Dapat di artikan bahwa ke empat tekanan di atas merupakan rata-rata dari tekanan setatik yang berada di bagian belakang kontraksi seksi uji, dapat di tulis dalam bentuk pengukuran yang absolut dan tekanan diferensialnya, sebagai berikut:

$$
\begin{aligned}
& P_{C}=\frac{\left\{\left(P_{s 1}-P_{s} 4\right)+P_{s} 4+\left(P_{s}-P_{s} 4\right)+P_{s} 4+\left(P_{s} 3-P_{s} 4\right)+P_{s} 4+P_{s} 4\right\}}{4} \\
& =\frac{\Delta P 14+\Delta P 24+\Delta P 34+4 P_{54}}{4} \\
& =P_{S} 4+\frac{\Delta P 14+\Delta P 24+\Delta P 34}{4}
\end{aligned}
$$

(O.De Vries. 4.1 Hal.34)

Kontrol tekanan diferensial, tekanan ini di definiskan sebagai berikut:

Control differential pressure merupakan nilai rata-rata dari tekanan diferensial yang di gunakan untuk mengontrol di terowongan angin, Dapat di artikan yaitu bahwa untuk rata-rata dua tekanan total (Pt) dikurangi dengan rata-rata empat tekanan setatik (Ps).

$$
\Delta P_{c}=\frac{P_{t 1}+P_{t 2}}{2}-\frac{P_{s} 1+P_{s} 2+P_{s} 3+P_{s} 4}{4}
$$

(O.De Vries. Hal.34)

Control diferential pressure dapat di nyatakan dalam bentuk pengukuran tekanan yang tercantum dalam table tunnel tranducer sebagai referensi tunnel dengan hal ini bisa digunakan untuk dengan mudah menurunkan beberapa perhitungan control diferential pressure dan dapat di tulis sebagai berikut:

$$
\begin{aligned}
\Delta P C & =\frac{P t 1+P t 2}{2}-\frac{P_{s 1}+P_{s 2}+P_{s 3}+P_{s 4}}{4} \\
& =\frac{\left\{2\left(P t 1-P_{s 1}\right)+P_{s 1}+2\left(P t 2-P_{s 2}\right)+P_{s 2}-P_{s 3}-P_{s} 4\right\}}{4} \\
& =\frac{\left\{2 \Delta P c 1-2 \Delta P_{c 2}+\left(P s 1-P_{s 4}\right)+\left(P s 2-P_{s} 4\right)+P_{s 4}-\left(P s 3-P_{s 4}\right)-P_{s} 4\right\}}{4} \\
& =\frac{\Delta P c 1+\Delta P_{c 2}}{2}+\frac{\Delta P 14+\Delta P 24-\Delta P 34}{4}
\end{aligned}
$$

(O.De Vries. 4.2 Hal.34)

\section{SifAT AliRAN}

\subsection{Aliran bebas teknan dinamik dan tekanan setatik}

Pada kalibrasi terowongan angin untuk mendapatkan nilai tekanan dinamik (digunakan untuk mengkoreksi efek dari kompresibilitas) dan setatik pada seksi uji yang kosong (empty box) dapat di hitung dari tekanan kontrol terowongan (tunnel control pressure), sebagai berikut:

* Tekanan dinamik pada seksi uji kosong (empty box)

$$
q_{00}=P_{C}\left\{G 0+G 1\left(\frac{\Delta P_{C}}{P_{C}}\right)+G 2\left(\frac{\Delta P_{C}}{P_{C}}\right)^{2}\right\}
$$

Tekanan setatik pada seksi uji kosong (empty box)

$$
P_{00}=P_{C}\left\{H 0+H 1\left(\frac{\Delta P_{C}}{P_{C}}\right)+H 2\left(\frac{\Delta P_{C}}{P_{C}}\right)^{2}\right\}
$$

(O.De Vries. 4.3 Hal.34)

(O.De Vries. 4.4 Hal.35)
Dari persamaan di atas untuk tekanan dinamik dan tekanan setatik pada 0 . merupakan konstanta nilainya di dapatkan dari hasil uji kalibrasi yang di lakukan pada seksi uji kosong (empty box), hasil pengukuran tersebut dibuat polynomial kuadrat terkecil sehingga dari hasil tersebut di dapatlah konstanta yang di inginkan. Dapat dikatakan bahwa hasil uji kalibrasi pada terowongan angin pada seksi uji kosong (empty box) bertujuan untuk mendapatkan nilai konstanta dari G0 G2 dan H0 H2, yang kemudian hasil nilai konstanta tersebut di simpan di dalam data base initpe.f pada data processing DARS sebagai referensi yang nantinya pada saat pengujian model di terowongan angin secara normal harus di gunakan untuk menghasilkan data hasil pengujian yang di perlukan.

Pengukuran dengan kecepatan rendah pada seksi uji kosong (empty box)

$$
q_{00}=G^{\prime} 0+G^{\prime} 1 \Delta P_{C}+G^{\prime} 2 \Delta P_{c^{2}}
$$


Perhitungan di atas dapat di nyatakan bahwa untuk mendapatkan koefisien konstanta G'0 G'2 itu diperlukan ke tepatan pengukuran pada tekanan diferensial tranducer untuk $\Delta P_{C}$ dan $\Delta P_{r e f}$ yang di lakukan pada kecepatan rendah di seksi uji kosong. Jadi hasil polynomial yang di peroleh dari pengukuran akan mendapatkan konstanta yang juga akan di simpan di initpe.f pada data processing DARS yang di khususkan pada setiap pengukuran dengan kecepatan yang sangat rendah.

\subsection{Setatik dan dinamik pada seksi uji kosong}

Tekanan setatik dan dynamic yang di lakukan pada seksi uji kosong dapat di ukur dengan menggunakan pitot static tube yang sudah di pasang di bagian tengah seksi uji yang kosong. Untuk mengukur tekanan setatik (Pref) pada pitot ststik tube harus dengan menggunakan tranduser yang absolut. Sedangkan untuk mengukur perbedaan tekanan total dan tekanan setatik ( $\Delta$ Pref $)$ harus dengan menggunakan tranduser diferensial. Tekanan setatik di bagian seksi uji yang kosong haru di ukur dengan menggunakan reference pitot setatik tube $\left(P_{r e f}\right)$ terlebih dahulu harus di koreksi dengan factor kalibrasi (f2) dikalikan ( $\Delta$ Pref $)$ dan tinggi (h) perbedaan antara pitot setatik dan tranduser, dan dapat di lihat pada persamaan rumus di bawah ini.

$P_{0}=$ Pref $+f 2 . \Delta$ Pref $-\rho g h \approx$ Pref $+f 2 . \Delta$ Pref $-10 h$

(O.De Vries. Apendix A.2 Hal.181)

di mana $\rho$ adalah densitas udara $[\mathrm{kg} / \mathrm{m} 3]$, g adalah percepatan gravitasi [m / s2] dan h adalah perbedaan ketinggian $[\mathrm{m}]$.

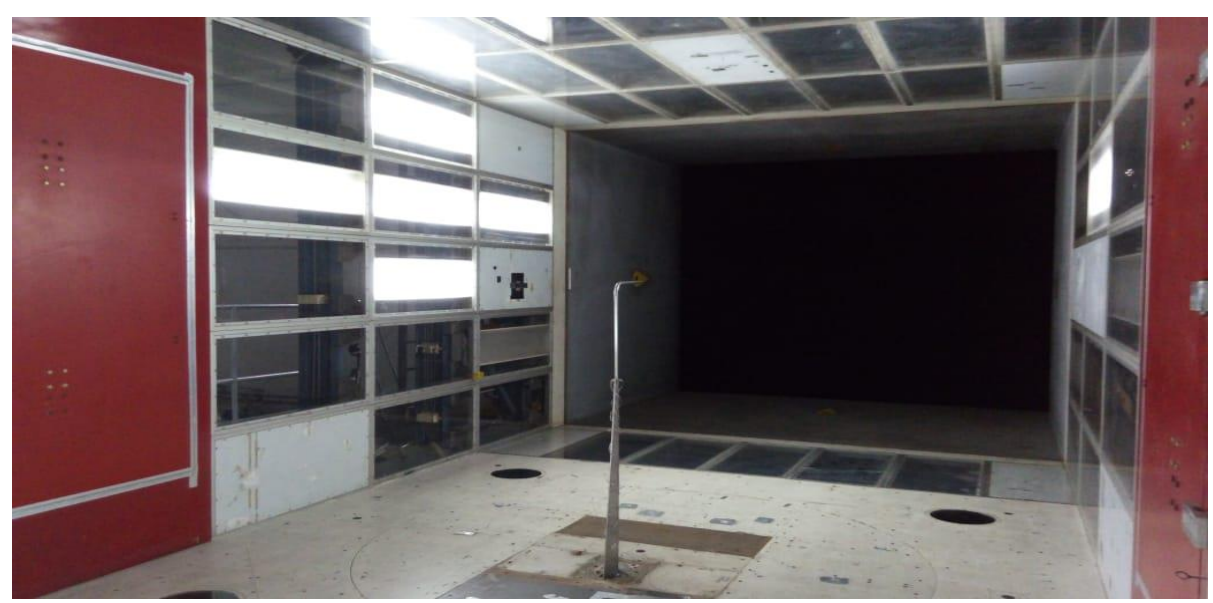

Gambar 3. pengukuran pitot statik tube untuk tekanan setatik dan dinamik. 


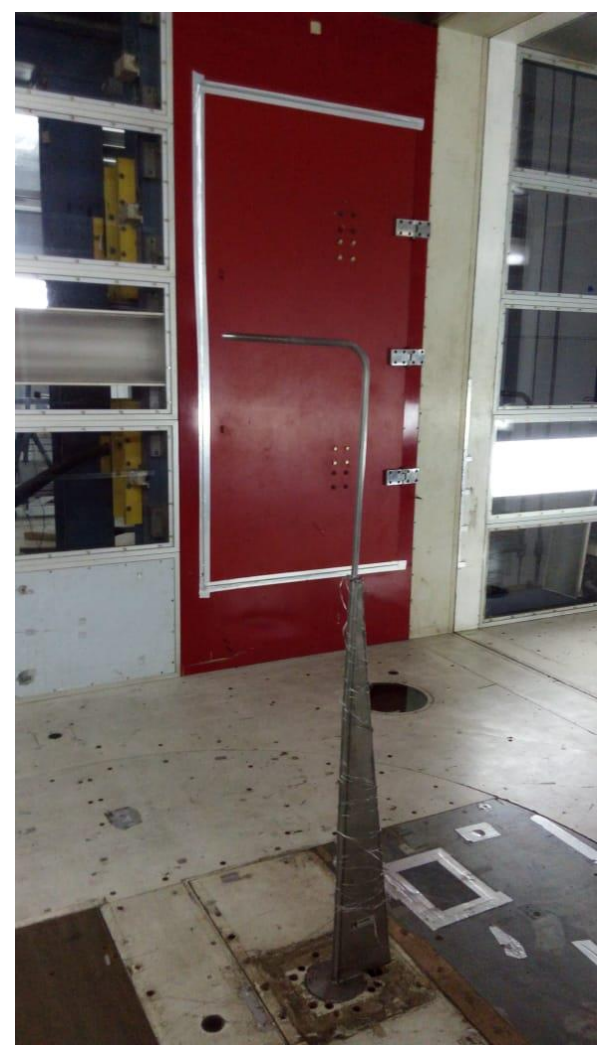

Gambar 4. pitot statik tube pada bagian tengah seksi uji.

\section{Metodologi Pengukuran}

\subsection{Data yang di sajikan}

Data yang harus di kumpulkan, di proses dan di sajikan dapat di lihat dalam table di bawah ini, adalah sebagai berikut:

Tabel 2. Proses data yang di sajikan

\begin{tabular}{|c|c|c|c|}
\hline No & Data & Symbol & Unit \\
\hline \multicolumn{4}{|c|}{ Data pengukuran } \\
\hline 1. & Kecepatan fan & $S f$ & {$[\mathrm{rpm}]$} \\
\hline 2. & Temperatur Udara & Tav & {$[\mathrm{K}]$} \\
\hline 3. & Kontrol Statik Pressure & $p c$ & {$[\mathrm{~Pa}]$} \\
\hline 4. & Total minus static pressure at control & $\Delta p c$ & {$[\mathrm{~Pa}]$} \\
\hline 5. & Static Pressure measured by Pitot tube & pref & {$[\mathrm{Pa}]$} \\
\hline 6. & Total minus static pressure of Pitot tube & spref & {$[\mathrm{Pa}]$} \\
\hline \multicolumn{4}{|c|}{ Data yang dihitung } \\
\hline 1. & Temperatur & T0 & {$[\mathrm{K}]$} \\
\hline 2. & Tekanan Statik di Center TS & p0 & {$[\mathrm{Pa}]$} \\
\hline 3. & Tekanan Dynamik di Center TS & q0 & {$[\mathrm{Pa}]$} \\
\hline 4. & Density & $\rho 0$ & {$\left[\mathrm{~kg} / \mathrm{m}^{3}\right]$} \\
\hline 5. & Velocity & $\mu 0$ & {$[\mathrm{~m} / \mathrm{s}]$} \\
\hline \multicolumn{4}{|c|}{ Faktor kalibrasi } \\
\hline 1. & G0 G2 & & {$[-]$} \\
\hline 2. & $\mathrm{H} 0 \sim \mathrm{H} 2$ & & {$[-]$} \\
\hline
\end{tabular}

\subsection{Prosedur}

Instrumentasi yang akan di pasang dapat di lihat pada gambar di bawah ini. 


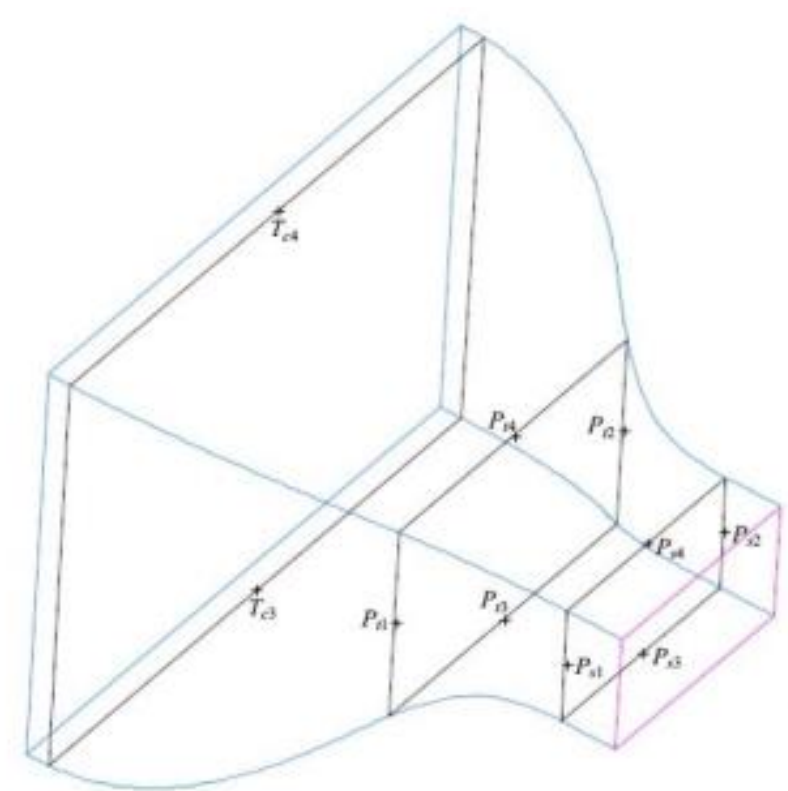

Gambar 5. Posisi Isntall peralatan Instrumentasi pada kalibrasi kecepatan angin di terowongan angin.

1. Empat pitot static taps, empat tekanan total dan dua probe suhu dipasang di empat dinding pada akhir kontraksi seperti ditunjukkan pada Gambar diatas.

2. Probe pitot statik yang terkalibrasi dipasang di bagian tengah uji $(\mathrm{x}=\mathrm{y}=\mathrm{z}=0,0 \mathrm{~m})$ dan ditengah turn table. Port tekanan statik tabung pitot dihubungkan ke transduser absolut pada Pt3. Port tekanan total dan tekanan statik dari tabung pitot dihubungkan ke transduser diferensial untuk $\Delta P_{c} 3$.

3. Memasang semua instrument dan menghubugkan dengan DARS (Data Acquisition, Reduction and Control System) control room ILST.

4. Fan drive on (menjalankan kipas di terowongan angin)

a. Setelah semua peralatan instrumen yang di perlukan untuk pengukuran sudah terpasang dengan lengkap, fan akan di jalankan dari 0 hingga rpm maksimum yang di perlukan dalam pengukurandengan interval 320 RPM dengan kecepatan angin $75 \mathrm{~m} / \mathrm{s}$.

b. Ketika sedang menaikan kecepatan berdasarkan tingkat kecepatan untuk mengatur agar setabil setidaknya ada waktu untuk menahan selama 60 detik pada tingkatan yang sudah ingin di capai.

c. Jika fan drive tiba-tiba mati pada saat pertengan pengambilan data, maka harus di ulang dari awal sebelum melaju hingga ke kecepatan yang lebih tinggi.

5. Data hasil pengukuran yang di perlukan sudah tersimpan di dalam data processing (DP) dalam bentuk raw data sehingga siap untuk di analisis dan dikaji ulang apakah sudah sesuai dengan yang di harapkan atau tidak.

\section{Hasil dan Pembahasan}

Pengukuran untuk menentukan performa kualitas kecepatan angin di lakukan di seksi uji kosong (empty box) di ILST BBTA3, yang bertujuan untuk mengetahui apakah kualitas aliran kecepatan angin di area seksi uji tersebut masih layak dan baik dan konsisten sehingga kedepannya bisa untuk di gunakan didalam rujukan berbagai pengujian model aerodinamika di terowongan angin.

Pengukuran kualitas angin di terowongan dilakukan dengan menempatkan pitot setatik probe ditengan seksi uji kosong dengan referensi pitot tersebut sudah di kalibrasi terlebih dahulu, Instrumentasi yang terpasang dilakukan sudah sesuai prosedur untuk pengukuran kalibrasi di terowongan angin, tekanan setatik pada pitot setatik tube (Pref) harus di ukur dengan menggunakan tranduser absolut, perbedaan antara tekanan total dengan tekanan setatik ( $\Delta$ Pref) telah di ukur dengan tranduser diferensial.

Berikut data hasil pengukuran untuk kalibrasi kualiatan aliran angin di terowongan angin dengan seksi uji kosong, data di ambil 3 kali pengambilan dan di rata-ratakan dengan waktu pengambilan 5 detik, adalah sebagai berikut : 
Tabel 3. Hasil pengukuran

\begin{tabular}{|c|c|c|c|c|c|c|c|c|c|c|c|c|c|c|}
\hline vo & PO & Q0 & VReal & PReal & QReal & Poo & Qoo & RHO & TO & PC & DPC & RPMFan & PowFan & Mo \\
\hline 0 & 100177.3 & 1 & 1.383333 & 100227.9 & 1.09 & 100177.5 & 1.09 & 1.144 & 301.9567 & 100320.9 & -3.23 & 0 & 0 & 0 \\
\hline 0 & 100174 & 1 & 1.633333 & 100223.7 & 1.523333 & 100173.3 & 1.523333 & 1.144 & 301.9067 & 100317.1 & -2.85 & 9.8 & 0 & 0 \\
\hline 0 & 100173 & 1 & 2.7 & 100222.5 & 4.173333 & 100172.1 & 4.173333 & 1.144 & 301.7667 & 100315.9 & -0.10333 & 19.7 & 0 & 0 \\
\hline 6.056667 & 100170 & 21 & 6.063333 & 100219.7 & 21.06333 & 100169.2 & 21.06333 & 1.145 & 301.5467 & 100312.8 & 16.47667 & 29.6 & 1 & 0 \\
\hline 8.493333 & 100169 & 41 & 8.48 & \begin{tabular}{|l|}
100219.3 \\
\end{tabular} & 41.17333 & 100168.8 & 41.16667 & 1.145 & 301.61 & 100312 & 36.72 & 39.4 & 2 & 0.001 \\
\hline 10.78667 & 100168 & 67 & 10.78 & 100218.2 & 66.51667 & 100167.5 & 66.5 & 1.145 & 301.61 & 100310.6 & 62.04333 & 49.6 & 3 & 0.001 \\
\hline- & - & - & - & - & - & - & - & - & - & - & - & - & - & - \\
\hline- & - & - & - & - & - & - & - & - & - & - & - & - & - & - \\
\hline- & - & - & - & - & - & - & - & - & - & - & - & - & - & - \\
\hline- & - & - & - & - & - & - & - & - & - & - & - & - & - & - \\
\hline 65.26 & 100113.7 & 2432.333 & 65.53667 & 100170.9 & 2453.11 & 100112.3 & 2431.937 & 1.142 & 302.1633 & 100228.6 & 2443.963 & 280.1 & 450 & 0.035 \\
\hline 67.73667 & 100109.7 & 2619.333 & 68.04 & 100168.1 & 2642.917 & 100108.8 & 2618.367 & 1.142 & 302.2833 & 100222.6 & 2633.703 & 290.3 & 495 & 0.038 \\
\hline 70.18667 & 100107.7 & 2810 & \begin{tabular}{|l|}
70.53667 \\
\end{tabular} & 100166.6 & 2837.987 & 100106.7 & 2809.71 & 1.141 & \begin{tabular}{|l|}
302.5367 \\
\end{tabular} & 100218.2 & 2827.337 & 300.1 & 535 & \begin{tabular}{|l|l|}
0.040667 \\
\end{tabular} \\
\hline 72.68333 & 100106 & 3012 & 73.06667 & \begin{tabular}{|l|}
100165.1 \\
\end{tabular} & 3043.817 & 100104.6 & 3011.327 & 1.14 & \begin{tabular}{|l|}
302.6667 \\
\end{tabular} & 100214.3 & 3033.03 & 310 & 590 & 0.043 \\
\hline 75.16667 & 100104 & 3220.333 & 75.59333 & 100163.7 & 3257.307 & 100102.5 & 3220.14 & 1.14 & 302.7333 & 100209.6 & 3245.807 & 320.2 & 660 & 0.046 \\
\hline 73.91667 & 100107 & 3112.333 & 74.32667 & 100166.7 & 3146.83 & 100105.9 & 3112.12 & 1.139 & 302.94 & 100214 & 3135.143 & 315.5333 & 620 & 0.045 \\
\hline 71.42 & 100114 & 2904 & \begin{tabular}{|l|}
71.79667 \\
\end{tabular} & 100173.4 & 2934.76 & 100113.3 & 2904.543 & 1.139 & 303.0967 & 100223.7 & 2923.277 & 305 & 560 & 0.042 \\
\hline 68.96333 & 100123 & 2707 & 69.31 & 100182.2 & 2734.37 & 100122.8 & 2708.107 & 1.138 & 303.2 & 100234.9 & 2723.07 & 295.5 & 500 & 0.039 \\
\hline 66.49 & 100129.3 & 2516 & \begin{tabular}{|l|}
66.79333 \\
\end{tabular} & 100188.3 & 2539.137 & 100129.6 & \begin{tabular}{|l|}
2516.467 \\
\end{tabular} & 1.138 & \begin{tabular}{|l|}
303.2667 \\
\end{tabular} & 100244 & 2528.82 & 284.9 & 460 & 0.036 \\
\hline 64.01667 & 100135.3 & 2332.333 & 64.3 & 100193 & 2352.967 & 100134.9 & 2333.48 & 1.138 & 303.3 & 100251.6 & 2342.373 & 275.3 & 410 & 0.034 \\
\hline- & - & - & - & - & - & - & - & - & - & - & - & - & - & - \\
\hline- & - & - & - & - & - & - & - & - & - & - & - & - & - & - \\
\hline- & - & - & - & - & - & - & - & - & - & - & - & - & - & - \\
\hline- & - & - & - & - & - & - & - & - & - & - & - & - & - & - \\
\hline 9.66 & 100193 & 53 & 9.693333 & 100242.6 & 53.59 & 100192.2 & 53.58 & 1.141 & 302.78 & 100335.5 & 48.65667 & 44.6 & 2 & 0.001 \\
\hline 7.376667 & 100192.7 & 31 & 7.4 & 100242.3 & 31.22667 & 100192 & 31.22333 & 1.141 & 302.7 & 100335.3 & 26.48333 & 34.7 & 1 & 0 \\
\hline 5.23 & 100194 & 16 & 5.246667 & 100243.9 & 15.70333 & 100193.6 & \begin{tabular}{|l|}
15.70333 \\
\end{tabular} & 1.141 & 302.66 & 100336.7 & 11.07 & 24.8 & 0 & 0 \\
\hline 0 & 100194 & 1 & 3.193333 & 100244.5 & 5.82 & 100194.2 & 5.82 & 1.141 & 302.6233 & 100337.3 & 1.29 & 15 & 0 & 0 \\
\hline 0 & 100194 & 1 & \begin{tabular}{|l|}
1.493333 \\
\end{tabular} & 100245.1 & 1.27 & 100194.8 & 1.27 & 1.142 & 302.54 & 100337.5 & -3.13 & 0 & 0 & 0 \\
\hline vo & PO & Q0 & VReal & PReal & QReal & Poo & Qoo & RHO & TO & PC & DPC & RPMFan & PowFan & Mo \\
\hline
\end{tabular}

Dengan memisalkan $\frac{q_{0}}{p_{c}}=y, \frac{p_{0}}{p_{c}}=z$, dan $\frac{\Delta p_{c}}{p_{c}}=x$, sehingga menjadi persamaan nonliner yaitu polinomial dengan orde dua atau biasa disebut dengan persamaan kuadrat

$$
\begin{aligned}
& y=G_{0}+G_{1} x+G_{2} x^{2} \\
& z=H_{0}+H_{1} x+H_{2} x^{2}
\end{aligned}
$$

dengan $G_{0} \sim G_{2}$ dan $H_{0} \sim H_{2}$ merupakan konstanta-konstanta persamaan yang akan dicari.

Tabel 4. Hasil perhitungan

\begin{tabular}{|c|c|c|c|}
\hline Q00/PC & P00/PC & DPC/PC & (DPC/PC)^2 \\
\hline $1.08651 E-05$ & 0.998570587 & $-3.21967 \mathrm{E}-05$ & $1.03663 \mathrm{E}-09$ \\
\hline $1.51852 \mathrm{E}-05$ & 0.998566545 & $-2.84099 \mathrm{E}-05$ & $8.07123 \mathrm{E}-10$ \\
\hline $4.16019 \mathrm{E}-05$ & 0.99856686 & $-1.03008 \mathrm{E}-06$ & $1.06106 \mathrm{E}-12$ \\
\hline 0.000209977 & 0.998568478 & 0.000164253 & $2.6979 \mathrm{E}-08$ \\
\hline- & - & - & - \\
\hline- & - & - & - \\
\hline- & - & - & - \\
\hline- & - & - & - \\
\hline 0.00031119 & 0.998571789 & 0.000263948 & $6.96687 \mathrm{E}-08$ \\
\hline 0.000156506 & 0.998573802 & 0.000110329 & $1.21724 \mathrm{E}-08$ \\
\hline $5.80043 \mathrm{E}-05$ & 0.998573479 & $1.28566 \mathrm{E}-05$ & $1.65293 \mathrm{E}-10$ \\
\hline $1.26573 \mathrm{E}-05$ & 0.9985778 & $-3.11947 \mathrm{E}-05$ & $9.7311 \mathrm{E}-10$ \\
\hline Q00/PC & P00/PC & DPC/PC & (DPC/PC)^2 \\
\hline & & \multicolumn{2}{c}{}
\end{tabular}

Dari perhitungan yang dilakukan menghasilkan grafik koefisien tekanan dinamik pada ruangan kosong dan grafik koefisien tekanan setatik pada area tengah seksi uji pada ruangan kosong, adalah sebagai berikut: 


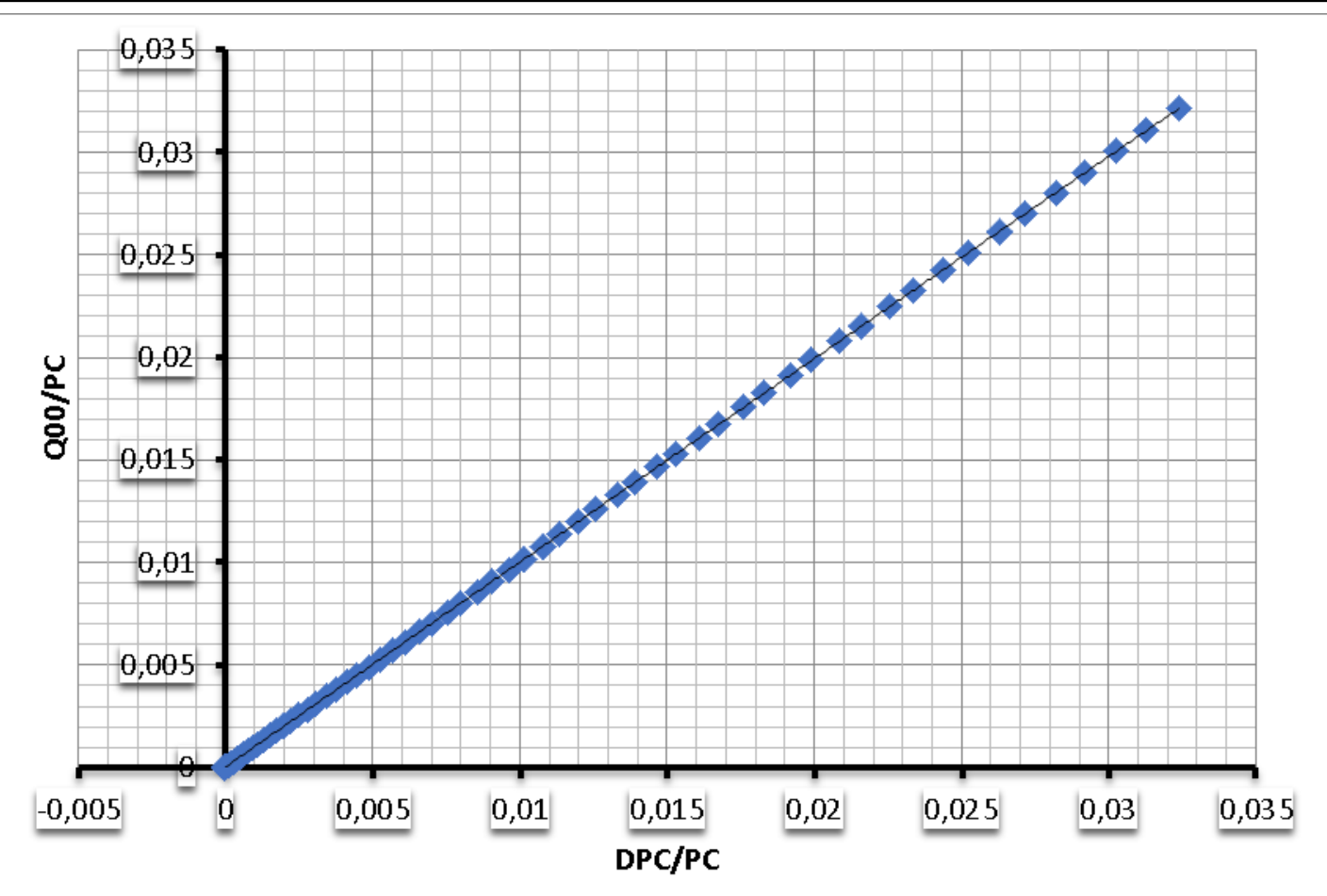

Gambar 6. Kurva hasil kalibrasi untuk tekanan dinamik di tengan seksi uji kosong

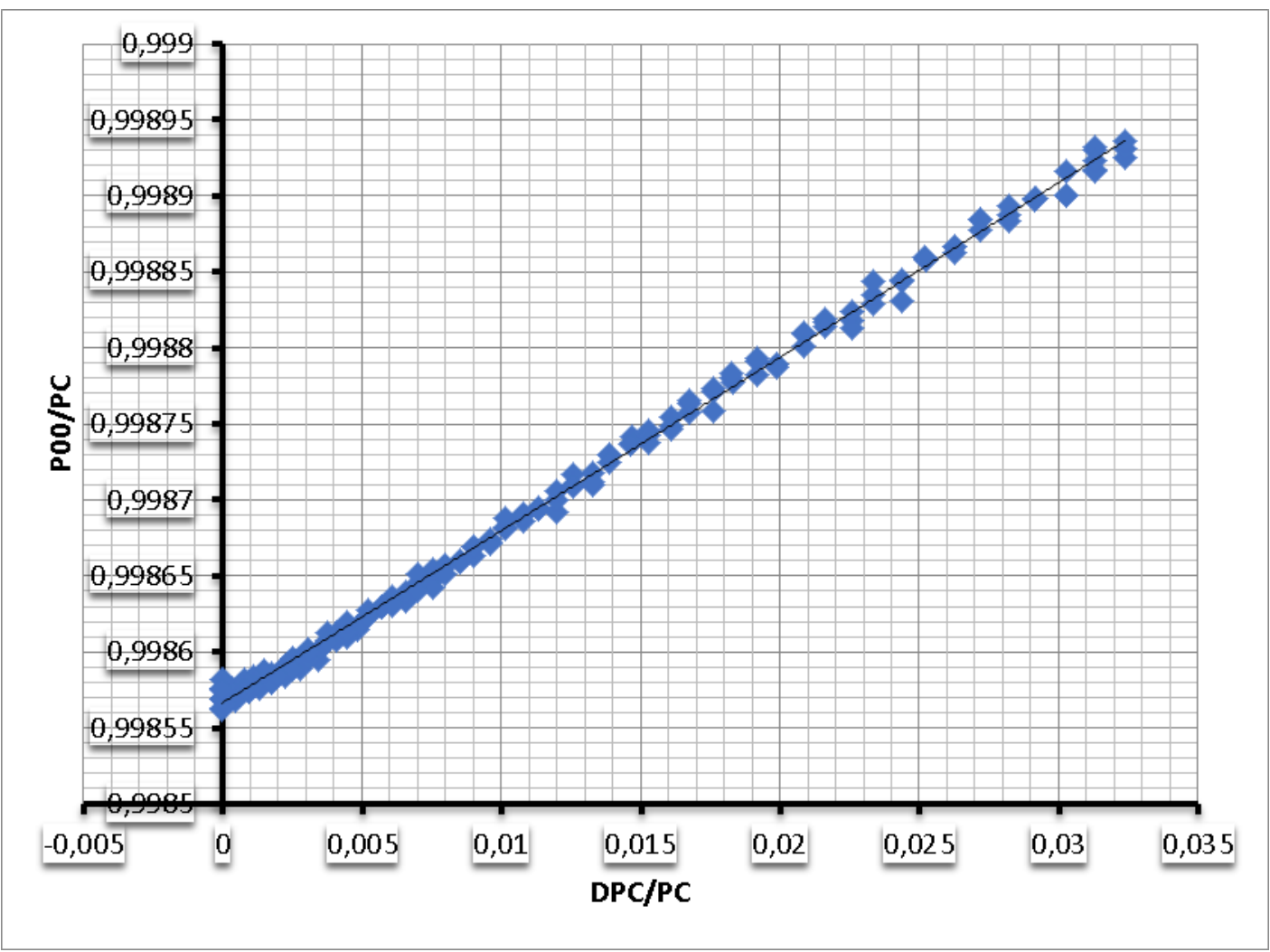

Gambar 7. Kurva hasil kalibrasi untuk tekanan setatik di tengah seksi uji kosong

Dengan demikian didapat hasil pengukuran kualitas kecepatan angin di terowongan angin ILST BBTA3 dengan koefisien konstanta kalibrasi yang nantinya digunakan sebagai referensi pada pengujianpengujian aerodinamika di terowongan angin yang akan di lakukan di ILST, persamaan tekanan statik dan dinamik di dalam seksi uji ILST sebagai fungsi tekanan statik kontrol dan tekanan diferensial kontrol sebagai berikut. 
Konstanta perhitungan tekanan dinamik di seksi uji :

$$
\begin{aligned}
& \frac{q_{00}}{P_{c}}=4,49221 \mathrm{E}-05+1,00168 \mathrm{E}+00 *\left(\frac{\Delta P_{c}}{P_{c}}\right)-3,35603 \mathrm{E}-01 *\left(\frac{\Delta P_{c}}{P_{c}}\right)^{2} \\
& \mathrm{G} 0=4,49221 \mathrm{E}-05 \\
& \mathrm{G} 1=1,00168 \mathrm{E}+00 \\
& \mathrm{G} 2=-3,35603 \mathrm{E}-01
\end{aligned}
$$

Konstanta perhitungan tekanan statik di seksi uji :

$$
\begin{aligned}
& \frac{P_{00}}{P_{c}}=9,98567 \mathrm{E}-01+1,12739 \mathrm{E}-02 *\left(\frac{\Delta P_{c}}{P_{c}}\right)+4,37821 \mathrm{E}-03 *\left(\frac{\Delta P_{c}}{P_{c}}\right)^{2} \\
& \mathrm{H} 0=9,98567 \mathrm{E}-01 \\
& \mathrm{H} 1=1,12739 \mathrm{E}-02 \\
& \mathrm{H} 2=4,37821 \mathrm{E}-03
\end{aligned}
$$

\section{KESIMPULAN}

Kalibrasi pada terowongan angin di seksi uji kosong (ruang kosong) untuk mendapatkan hasil pegukuran kualitas kecepatan angin yang sesuai dan di butuhkan sebagai referensi dan mengkolerasikan perhitungan matematis sehingga di dapatkan hasil sebagai berikut :

* Pengukuran pada tekanan dinamik pada ruang kosong / seksi uji kosong yang di koreksi dengan efek kompresibilitasnya, sebagai berikut:

$$
\begin{aligned}
& q_{00}=P_{C}\left\{G 0+G 1\left(\frac{\Delta P_{c}}{P_{c}}\right)+G 2\left(\frac{\Delta P_{c}}{P_{c}}\right)^{2}\right\} \\
& \frac{q_{00}}{P_{c}}=G 0+G 1\left(\frac{\Delta P_{C}}{P_{C}}\right)+G 2\left(\frac{\Delta P_{C}}{P_{C}}\right)^{2}
\end{aligned}
$$

(O.De Vries. 4.10 Hal.37)

$$
\frac{q_{00}}{P_{c}}=4,49221 \mathrm{E}-05+1,00168 \mathrm{E}+00 *\left(\frac{\Delta P_{c}}{P_{c}}\right)-3,35603 \mathrm{E}-01 *\left(\frac{\Delta P_{c}}{P_{c}}\right)^{2}
$$

Pengukuran pada tekanan setatik pada ruang kosong / seksi uji kosong yang dapat di hitung dari control tekanan pada terowongan, sebagai berikut:

$$
\begin{aligned}
& P_{00}=P_{c}\left\{H 0+H 1\left(\frac{\Delta p_{c}}{P_{c}}\right)+H 2\left(\frac{\Delta P_{c}}{P_{c}}\right)^{2}\right\} \\
& \frac{P_{00}}{P_{c}}=H 0+H 1\left(\frac{\Delta P_{c}}{P_{c}}\right)+H 2\left(\frac{\Delta P_{c}}{P_{c}}\right)^{2}
\end{aligned}
$$

(O.De Vries. 4.11 Hal.37)

$$
\frac{P_{00}}{P_{c}}=9,98567 \mathrm{E}-01+1,12739 \mathrm{E}-02 *\left(\frac{\Delta P_{c}}{P_{c}}\right)+4,37821 \mathrm{E}-03 *\left(\frac{\Delta P_{c}}{P_{c}}\right)^{2}
$$

Untuk data eksperimen yang berbeda tidak menutup kemungkinan persamaan akan didekati dengan polinomial dengan orde yang lebih tinggi untuk mendapatkan hasil yang lebih akurat.

Dalam tulisan ini hanya menampilkan proses pengukuran hingga menghasilkan data yang di perlukan untuk perhitungan dan referensi data yang di perlukan. Perlu diketahui bahwa data hasil pengukuran ini bisa dijadikan sebagai bahan rujukan bahwa kualitas aliran kecepatan angin di sekitar seksi uji dinyatakan layak dan konsisten sehingga perlunya pembanding dengan data hasil pengukuran yang sudah pernah di lakukan, ini akan di bahas pada tulisan berikutnya mengenai konsistensi hasil data pengukuran. 


\section{Daftar Pustaka}

[1] AIAA-GTTC Wind Tunnel Calibration Methodology Working Group (2003), Recommended Practice - Calibration of Subsonic and Transonic Wind Tunnels, AIAA R-093-2003, Reston VA.

[2] Jaarsma, F. (1997), "General Design Aspects of Low Speed Wind Tunnel," AGARD CONFERENCE PROCEEDING 585, (3-1)-(3-15), AGARD.

[3] O.de Vries. 1987, "Nationaal Lucht-En Ruimtevaartlaboratorium,"Equatin for data processing of the ILST, Netherland.

[4] Novan.Risnawan,ST, 2018, Teknikal Report Pengukuran Performa Kecepatan Aliran Angin di Seski Uji ILST, BBTA3-BPPT.

[5] Pope,A, 1961, Wind Tunnel Calibration Techniques, North Atlantic Treaty Organization - Advisory Group For Aeronautical Research And Development, Sandia Corporation.

[6] Sulistya,SSi, 2018, Teknikal Dokumen Prosedur Kalibrasi Aliran Wind Tunnel, BBTA3-BPPT.

[7] Wiriadidjaja, S. 1987, ILST Test Report On The Empty Test Section Calibration, Technical Report, LAGG - BPPT. 